\title{
Giant Insulinoma in a Patient with Multiple Endocrine Neoplasia-Type I: A Case report
}

\author{
Hideo KATAOKA, Fumo OTSUKA, TaKayoshi YAMAUCHI, Masayuki KISHIDA, \\ MASAMI TAKAHASHI, TAKASHI TAMIYA*, YUKARI MIMURA**, \\ TOSHIO OGURA*** AND HIROFUMI MAKINO
}

\author{
Department of Medicine III, Okayama University Medical School, 2-5-1 Shikata-cho, Okayama 700-8558, Japan \\ * Department of Neurosurgery, Okayama University Medical School, 2-5-1 Shikata-cho, Okayama 700-8558, Japan \\ ** Faculty of Education, Okayama University, 1-1-1 Tsushima-naka, Okayama 700-0082, Japan \\ *** Health and Medical Center, Okayama University, 1-1-1 Tsushima-naka, Okayama 700-0082, Japan
}

\begin{abstract}
We report a case of giant cystic insulinoma constituting part of multiple endocrine neoplasia (MEN) type I. A 29-year-old Japanese man presented with a history of recurrent hypoglycemic attacks. Endocrine examination showed hyperinsulinemia discordant with hypoglycemia, and a giant cystic insulinoma $(11 \times 10 \mathrm{~cm})$ located in the pancreatic tail was detected radiologically. Hyperprolactinemia due to pituitary adenoma and hyperparathyroidism due to parathyroid hyperplasia were also present. The insulinoma, prolactinoma and hyperplastic parathyroid gland were surgically removed. Fluorescent microsatellite analysis detected loss of heterozygosity (LOH) in chromosome 11 q13 in DNA samples from all resected tissues but not from white blood cells. This is a rare case of MEN type I because of the giant cystic insulinoma and the evidence of common LOH detected in all MEN type I tissues.
\end{abstract}

Key words: Multiple endocrine neoplasia (MEN) type I, Insulinoma, Prolactinoma, Hyperparathyroidism, Loss of heterozygosity (LOH), Chromosome 11q13

(Endocrine Journal 46: 429-435, 1999)

MULTIPLE endocrine neoplasia (MEN) type $I$ is an autosomal dominant inherited multitumor disorder consisting of primary hyperparathyroidism, pancreatic endocrine tumor, and pituitary adenoma. The gene causing MEN type I is localized in chromosome 11q13 as shown in genetic mapping studies, which have investigated MEN type I-related tumors for the loss of heterozygosity $(\mathrm{LOH})$, as well as in segregation studies in pedigrees involving MEN type I [1, 2]. Recently the gene responsible for MEN type I was completely identified, and is considered to be a tumor suppressor gene $[1,3]$.

Pancreatic islet cell tumors are found in approxi-

Received: December 7, 1998

Accepted: March 12, 1999

Correspondence to: Hideo KATAOKA, M.D., Department of Medicine III, Okayama University Medical School, 2-5-1

Shikata-cho, Okayama, 700-8558, Japan mately $80 \%$ of patients with MEN type I [4]. Among the pancreatic involvement in MEN type I, gastrinomas are reportedly the most common tumors, followed by insulinoma [5]. As for the insulinoma in MEN type 1, to our knowledge there have been no reports on the giant insulinoma complication, and moreover, cystic insulinoma is also a very rare condition in MEN type I.

We present here a case of MEN type I with multiple insulinomas including a giant cystic insulinoma, together with hyperparathyroidism and pituitary prolactinoma. Furthermore, we also show in this patient a relatively widespread LOH around chromosome 11q13 of genomic DNA derived from these endocrinopathies. 


\section{Case Report}

A 29-year-old Japanese man was referred to our hospital in September 1996 with a history of frequent episodes of drowsiness and loss of consciousness since December 1995. During admissions to the local hospital, these attacks were found to be caused by hypoglycemia (blood glucose $20-30 \mathrm{mg} / \mathrm{dL}$ ), which rapidly improved after glucose injections. The past medical history was unremarkable except for the resection of a lipoma in the occipital region in 1991. The patient was $177 \mathrm{~cm}$ tall and weighed $91 \mathrm{~kg}$, fully conscious with no remarkable findings on palpation of the abdomen, thyroid and lymph nodes. Neurological and ophthalmologic examinations were normal. Laboratory tests on admission showed mild hypercalcemia $(10.3 \mathrm{mg} / \mathrm{dL}$ : normal $8-10)$, hypophosphatemia $(2.4 \mathrm{mg} / \mathrm{dL}$ : normal $3-5)$ and a moderate abnormality of liver function tests. The 1.5 -hour postprandial blood glucose was $114 \mathrm{mg} / \mathrm{dL}$, but the levels of serum immunoreactive insulin (IRI; $69.1 \mu \mathrm{U} / \mathrm{mL}$ : normal $<11.7)$ and $C$-peptide immu- noreactivity (CPR; $6.4 \mathrm{ng} / \mathrm{mL}$ : normal 1.5-3.5), and the ratio of IRI/blood glucose (Fajans index; 0.61 : normal $<0.3$ ) were all noticeably increased. The serum pro-insulin level was also increased to 67.2 pmol/L (normal 2.9-4.3). The daily profile of blood glucose and insulin levels showed a discordant IRI increase with hypoglycemia. Abdominal computed tomography (CT) demonstrated a giant tumor $(11 \times 10 \mathrm{~cm})$ in the tail region of the pancreas, consisting of a large cystic component, calcification of certain segments of the wall and a solid lesion with enhancement (Fig. 1A). No metastatic lesions were detected radiologically in other organs or lymph nodes. Abdominal angiography showed a hypervascular lesion supplied by a branch of the splenic artery (Fig. 1B). Percutaneous transhepatic portal vein catheterization (PTPC) demonstrated high IRI levels in serum samples obtained from several segments of the splenic vein in the body region of the pancreas. The serum gastrin level was within normal limits in all PTPC samples. A further assessment of the endocrine system showed marked hyperprolactinemia (serum prolactin, $2,332 \mathrm{ng} / \mathrm{mL}$ : normal $<30$ ) and

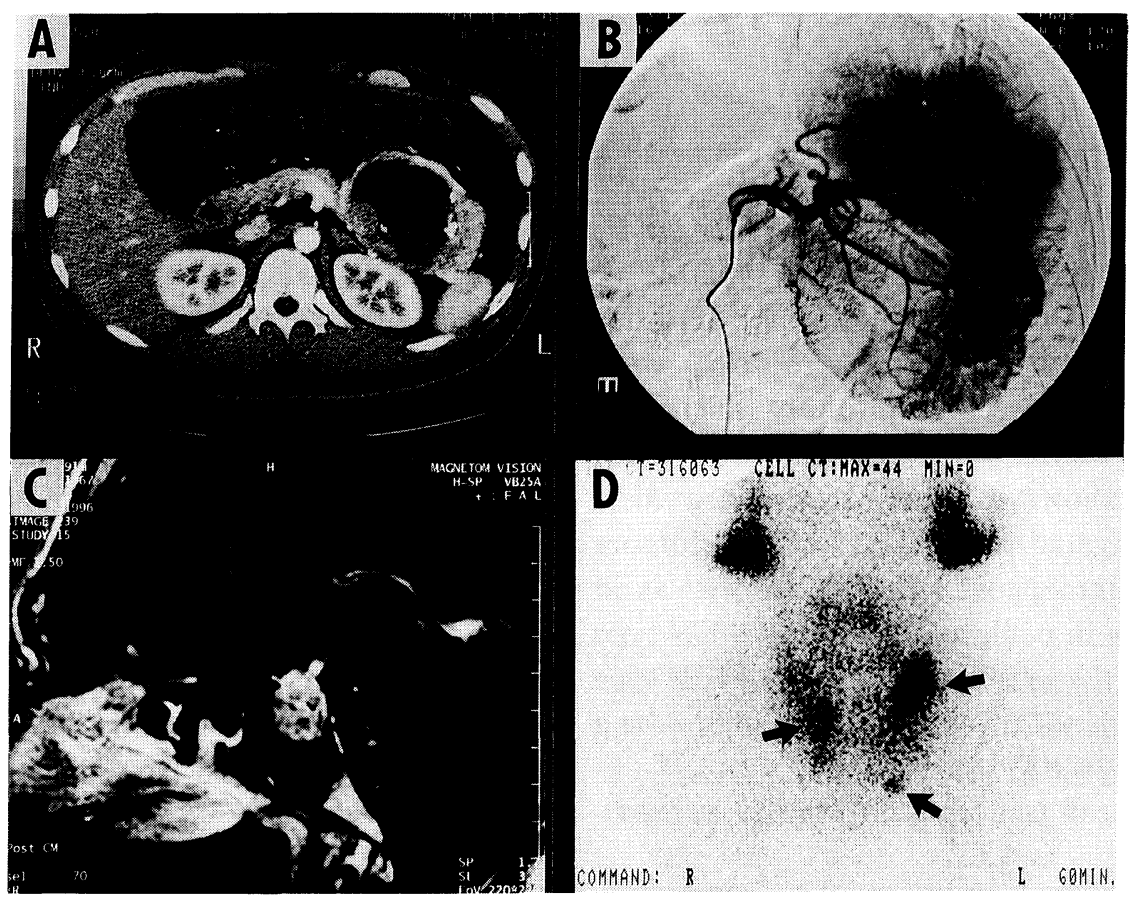

Fig. 1. Radiological findings. A: Abdominal computed tomography demonstrating a giant tumor $(11 \times 10 \mathrm{~cm})$ in the tail region of the pancreas, consisting of a large cyst, calcification of a portion of the wall and a solid lesion with enhancement. B: Abdominal angiography showing a hypervascular lesion supplied by a branch of the splenic artery. C: Cranial magnetic resonance imaging showing a pituitary tumor occupying the sella region with gadolinium enhancement. D: ${ }^{99 \mathrm{~m} T c-M I B I}$ scintigraphy of the thyroid region showing three enlarged poles of the parathyroid glands (arrows). 
hyperparathyroidism (serum hypersensitive parathyroid hormone, $670 \mathrm{pg} / \mathrm{mL}$ : normal 230-560). Cranial magnetic resonance imaging (MRI) showed a pituitary tumor occupying the sellar region (Fig. 1C). Cervical ultrasonography, CT, and 99mTc-methoxyisobutylisonitrile (MIBI) scintigraphy (Fig. 1D) showed three enlarged poles of the parathyroid glands. Based on the results of these investigations, the patient was diagnosed as MEN type I consisting of insulinoma, prolactinoma and hyperparathyroidism. The family history was unremarkable except for a history of cerebral infarction in the father. Unfortunately the immediate family members refused endocrine and radiological examinations.

Distal pancreatectomy for the giant insulinoma extending from the pancreatic body to the tail was performed in December 1996. The resected insulinoma was well encapsulated with dark-reddish fibrous tissue and included a cystic lesion, measuring $10.5 \times 9 \times 4 \mathrm{~cm}$, which contained a bloodstained exudate. The exudate contained very high concentrations of IRI. Histologically, the insulinoma was composed of multiformed cells with round nuclei, forming solid nests (Fig. 2A-C), but there was no evidence of extracapsular invasion or metastasis to regional lymph nodes. Immunohistochemically, cells of the main tumor were positive for insulin (Fig. 2D) and chromogranin-A, but negative for gastrin, glucagon, pancreatic polypeptide, somatostatin, and vasoactive intestinal peptide (VIP) (data on figure not shown).

Blood glucose concentrations and IRI levels returned to normal postoperatively without medication. Subsequently, the patient underwent transsphenoidal surgery for removal of the prolactinoma in April 1997. The resected prolactinoma was histopathologically confirmed to be a pituitary adenoma. Oral administration of bromocriptin was required for improvement of persistent hyperprolactinemia after surgery. Finally, total parathyroidectomy and autoimplantation of a portion of the resected parathyroid were performed in March 1998. Histological examination of the resected parathyroid showed hyperplasia and predominant presence of chief cells. After parathyroidectomy, the patient became eucalcemic with oral replacement of calcium and vitamin $\mathrm{D}$.

\section{Analysis of $\mathrm{LOH}$ in resected tissues and peripheral blood}

To analyze LOH, genomic DNAs were extracted

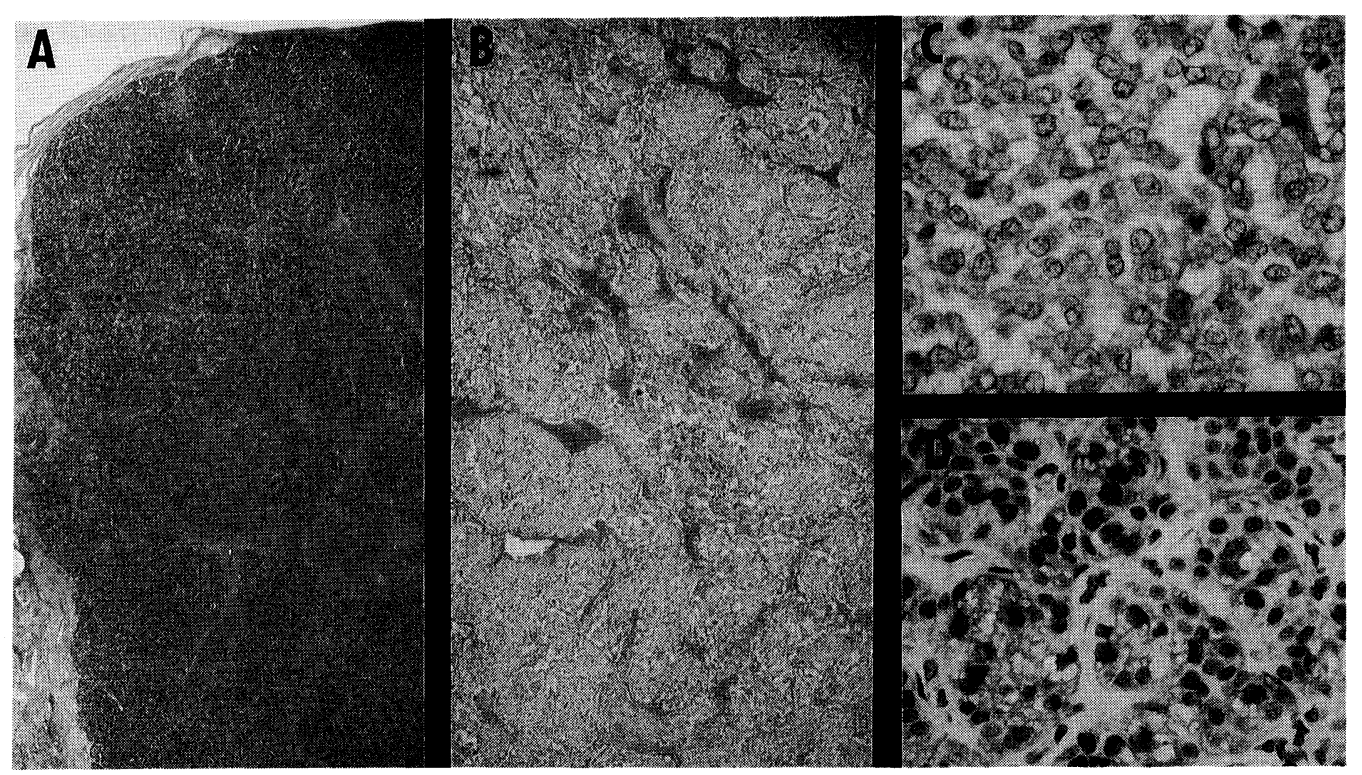

Fig. 2. Histological examination of giant insulinoma. A-C: Hematoxylin-eosin staining of the insulinoma. The insulinoma was well encapsulated and composed of multiformed cells with round nuclei, forming solid nests (magnification: A, $\times 10$; B, $\times 40 ; C, \times 400$ ). D: Immunohistochemistry of the insulinoma showing tumor cells positive for insulin $(\times 400)$. 
from the microdissected insulinoma, surgically resected prolactinoma and hyperplastic parathyroid tissue, and peripheral white blood cells (WBC). $\mathrm{LOH}$ in tumors was examined with respect to 5 microsatellite markers flanking the MEN I gene on chromosome 11q13: centromere-D11S913, D11S1314, D11S906, D11S1354, and D11S931-telomere $[6,7]$. The control study was performed with genomic DNA derived from WBC of a normal male subject. Allelic losses were assessed according to the methods reported by Tanaka et al. [8] with minor modifications. In brief, five microsatellite markers were amplified from the abovementioned five samples of DNAs (100 ng). One of each primer pair was labeled with fluorescent dye (Perkin-Elmer Cetus, Norwalk, CT). Polymerase chain reaction (PCR) was performed under the following conditions: 34 cycles of denaturation at $94^{\circ} \mathrm{C}$ for $3 \mathrm{~min}$, annealing at $58^{\circ} \mathrm{C}$ for $2 \mathrm{~min}$, and extension at $72^{\circ} \mathrm{C}$ for $1 \mathrm{~min}$. Gel-electrophoresis was performed with $6 \%$ polyacrylamide denaturing gels at $1,500 \mathrm{~V}$ for $120 \mathrm{~min}$ and it was analyzed with a automated fluorescent DNA sequencer (Perkin-Elmer Cetus, Norwalk, CT). LOH reflected a complete absence or reduced fluorescent peak of one of the constitutional alleles that could be detected visually. Microsatellite analysis showed positive $\mathrm{LOH}$ in the 11q13 region in all DNA samples obtained from insulinoma, prolactinoma and hyperplastic parathyroid tissue in the regions of all the five microsatellite markers (Fig. 3).
In contrast, $\mathrm{LOH}$ was not detected in the DNAs from WBC of the patient and normal control.

\section{Discussion}

MEN type I is an autosomal dominant inherited disorder consisting of primary hyperparathyroidism, pancreatic endocrine tumor, and pituitary adenoma [4]. Recent genetic studies of MEN type I have successfully mapped the MEN type I gene in the chromosomal region 11q13 [1]. The MEN type I gene consists of 1 untranslated exon and 9 coding exons with a $1,830 \mathrm{bp}$ coding region that encodes a novel 610 amino acid protein, termed MENIN. Although it has no homology to previously known proteins and its function remains unknown [1], the identified gene in MEN type I is thought to play an important role in the suppression of tumorigenesis [1, 3].

Pancreatic tumors originating in islet cells are common findings in MEN type I. In a review of 106 patients with MEN type I, Yoshimoto et al. [9] reported that pancreatic involvement was present in 66 patients. In this group of patients, $52 \%$ had Zollinger-Ellison (Z-E) syndrome while $42 \%$ had insulinoma. Insulinomas in MEN type I are frequently multicentric and $76 \%$ of insulinomas associated with MEN type I are of the multiple type [5]. In the present case, the insulinomas also showed a multicentric progression. As for the size of insulinomas,

\section{$\begin{array}{lllll}\text { D11S913 D11S1314 } & \text { D11S906 } & \text { D11S1354 } & \text { D11S931 }\end{array}$}
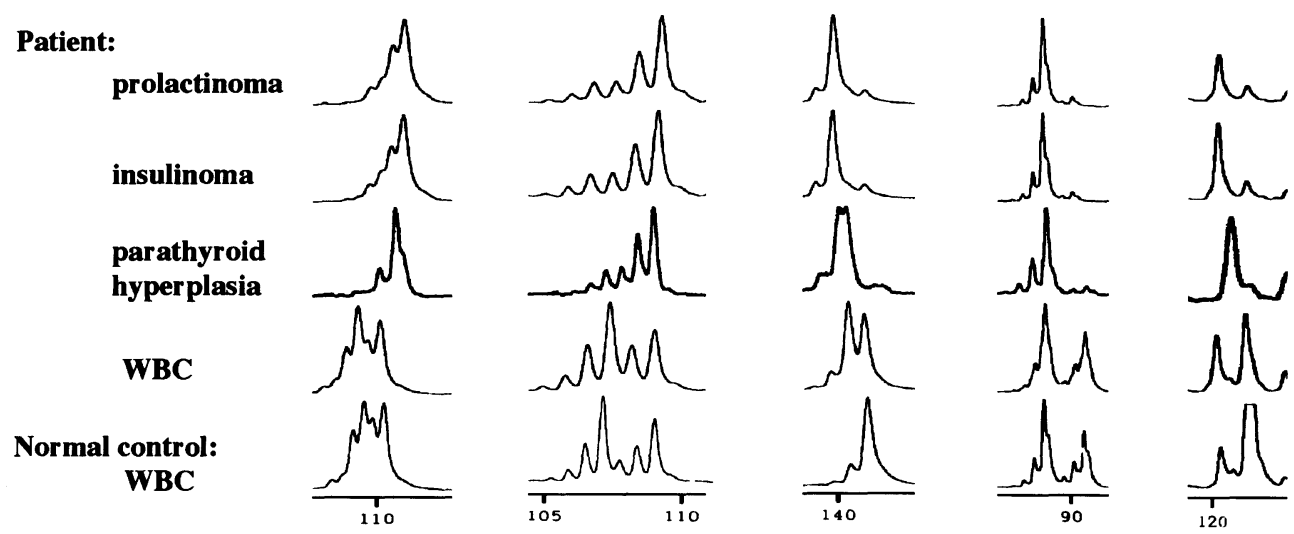

Fig. 3. Fluorescent microsatellite analysis of LOH. The microsatellite analysis showed that LOH of the $11 \mathrm{q} 13$ region was positively detected in all the DNAs obtained from insulinoma, prolactinoma and parathyroid hyperplasia in the regions of all the five microsatellite markers. In contrast, LOH alleles were not detected in the DNAs from white blood cells of the patient and normal control. 
irrespective of the association with MEN I, the majority of these tumors are less than $2 \mathrm{~cm}$ in diameter [10]. In spite of the availability of radiological examination, it is usually too difficult to localize such small insulinomas. Nevertheless, one of the present insulinomas was extremely large, with cystic changes. A careful examination of the literature showed that only five cases [11-15] have been previously described as "huge" insulinomas, but cystic formation of pancreatic tumors causing hyperinsulinemia was reported in only three cases [14-16]. To the best of our knowledge, the present case is the first report of a giant cystic insulinoma associated with MEN type I. Since the growth of insulinoma is usually slow $[17,18]$, it is likely that the development of the tumor in our patient occurred well before the manifestation of hypoglycemia. With regard to the cystic evolution of pancreatic tumors, a slowly growing tumor such as insulinoma tends to be encapsulated in a fibrous tissue, which reduces its vascularization and causes ischemia and subsequent central necrosis, eventually followed by cystic degeneration $[19,20]$. Goto et al. said that the cystic degeneration possibly limited the number of insulinproducing tumor cells [16], which may contribute to concealment of the clinical symptoms of insulinoma despite the expansive growth of the tumor. On the other hand, based on the clinical presentation, it is possible that the giant insulinoma was at first a nonfunctioning tumor but later transformed into an insulin-secreting functioning tumor. Strasser et al. reported that the cystic degeneration of islet cell tumors could be a bad prognostic indicator i.e. of malignant potential, whereas with the solid form of it there is a better life expectancy [21]. Although the insulinomas in our case did not have the typical features of malignancy on histopathological examination, or metastasize to other organs, a careful long-term follow-up is necessary in patients with MEN type I and their families because multihormonal tumors are frequently observed in this neoplastic condition even when only one component is clinically apparent [22].

Several mutations have been identified in the MEN I gene [1, 23, 24], but the correlation between such mutations and the clinical manifestations of endocrinopathies has not been clarified [23]. In the present case, we performed LOH analysis around chromosome 11q13 loci on all three resected endo- crine tissues and peripheral WBC. The five microsatellite regions used for $\mathrm{LOH}$ detection in the present analysis were selected in about the 13.1 to 13.5 centriMorgans $(\mathrm{cM})$ region of chromosome $11 \mathrm{q}$, which has been considered to include the gene responsible for MEN type I $[6,7]$. LOH was detected in DNAs derived from giant insulinoma, prolactinoma and hyperplastic parathyroid tissues in all of the five microsatellite regions, indicating that LOH was widely present in endocrine tumors comprising MEN type I. These findings suggest that the widespread allelic losses of chromosome 11q13 might be associated with the progression of insulinoma of MEN type I, although we cannot be involved in discussing whether the LOH could be shown in normal tissue of the affected organs or not in the present study. But the lack of LOH in DNA from WBC indicates that tumorigenesis of MEN type $I$ is not initiated at the genomic level but rather occurrs on the de novo endocrine organ level, as is explained by the Knudson's two-hit theory applied to retinoblastoma [1, 25]. Because multiple affected tissues have rarely been obtained from the same patient, the detection of common LOH in DNAs from three different endocrine organs in our case seems to add valuable information to our understanding of the pathogenesis of MEN type I. Unfortunately we were unable to perform $\mathrm{LOH}$ analysis in other members of the family. Such analysis would have been helpful in determining the genetic penetration of the genes responsible for MEN type I.

In conclusion, we have described in this report the first case of giant cystic insulinoma associated with MEN type I. A relatively widespread LOH of the chromosome 11q13 region was also detected in all neoplastic endocrine tissues including insulinoma, prolactinoma and hyperplastic parathyroid tissue. The present case suggests the complexity of clinical manifestations of MEN type I as well as the variability of growth of insulinoma with MEN type I. Further studies are necessary to elucidate the interrelationship between genetic and clinical varieties.

\section{Acknowledgment}

We are indebted to Dr. T. Hadama and his colleagues at the Gene Diagnostic Center, Otsuka Assay Lab., (Otsuka Pharmaceutical Co. Ltd., Tokushima, 
Japan) for their instructions and suggestions regard- ing the detection of loss of heterozygosity.

\section{References}

1. Chandrasekharappa SC, Guru SC, Manickam P, Olufemi SE, Collins FS, Emmert-Buck MR, Debelenko LV, Zhuang Z, Lubensky IA, Liotta LA, Crabtree JS, Wang Y, Roe BA, Weisemann J, Boguski MS, Agarwal SK, Kester MB, Kim YS, Heppner C, Dong Q, Spiegel AM, Burns AL, Marx SJ (1997) Positional cloning of the gene for multiple endocrine neoplasia-type I. Science 276: 404-407.

2. Thakker RV (1995) Multiple endocrine neoplasia type I. In: DeGroot LJ (ed) Endocrinology, $3^{\text {rd }}$ ed. Philadelphia: WB Saunders 2815-2831.

3. Thakker RV (1998) Editorial: multiple endocrine neoplasia-syndrome of the twentieth century. $J$ Clin Endocrinol Metab 83: 2617-2620.

4. Gagel RF (1998) Multiple endocrine neoplasia. In: Wilson JD, Foster DW, Kronenberg HM, Larsen PR (eds). Williams Textbook of Endocrinology-9th ed. Philadelphia: WB Saunders, 1627-1649.

5. Eberle F, Grün R (1981) Multiple endocrine neoplasia, Type I. Ergebn Inn Med Kiderhelik 64: 75-149.

6. Courseaux A, Grosgeorge J, Gaudray P, Pannett AAJ, Forbes SA, Williamson C, Bassett D, Thakker RV (1996) Definition of the minimal MEN I candidate area based on a $5-\mathrm{Mb}$ integrated map of proximal 11q13. Genomics 37: 354-365.

7. Gyapay G, Morissette J, Vignal A, Dib C, Fizames C, Millasseau P, Marc S, Bernardi G, Lathrop M, Weissenbach J (1994) The 1993-94 Genethon human genetic linkage map. Nature Genet 7 ( $2 \mathrm{spec} \mathrm{No})$ : 246-339.

8. Tanaka C, Yoshimoto K, Yang P, Kimura T, Yamada S, Moritani M, Sano T, Itakura M (1997) Infrequent mutations of p27 $7^{\text {Kipl }}$ gene and trisomy 12 in a subset of human pituitary adenomas. $J$ Clin Endocrinol Metab 82: 3141-347.

9. Yoshimoto K, Saito S (1991) Clinical characteristics in multiple endocrine neoplasia Type I in Japan. Folia Endocrinol 67: 764-774.

10. Soga J, Yakuwa Y (1994) Pancreatic endocrinomas: a statistical analysis of 1,857 cases. J Hepat Bil Pancr Surg 1: 522-529.

11. Arensman RM, Glassford GH (1976) Giant insulinoma. Am J Surg 131: 603-604.

12. Bogacki W, Niezabitowski A, Kowalczyk J, Spyt T, Mleczko A, Kurek S (1981) Case of hormonally inactive giant pancreatic insulinoma. Nowotwory 30: 397-402.

13. da Silva AL, Nunes TA, Braga $\mathrm{W}$ dos R, Sobrinho GB, Ferreira AL, da Silveira CM (1990) Giant insuli- noma. Rev Hosp Clin Fac Med Sao Paulo 45: 72-74.

14. Pogany AC, Kerlan RK, Karam Jh, Le Quesne LP, Ring EJ (1984) Cystic insulinoma. AJR 142: 951-952.

15. Marrano D, Campione O, Santini D, Piva P, Alberghini M, Casadei R (1994) Cystic insulinoma: a rare islet cell tumor of the pancreas. Eur J Surg 160: 519-522.

16. Goto $M$, Nakano I, Sumi $K$, Yamaguchi H, Kimura T, Sako Y, Nawata H, Tanaka M, Nagai E (1994) Cystic insulinoma and nonfunctioning islet cell tumor in multiple endocrine neoplasia type I. Pancreas 9: 393-395.

17. Modlin IM, Lewis JJ, Ahlman H, Bilchik AJ, Kumar RR (1993) Management of unresectable malignant endocrine tumors of the pancreas. Surg Gynecol Obstet 176: 507-518.

18. Fraker DL, Norton JA (1989) The role of surgery in the management of islet cell tumors. Gastroenterol Clin North Am 18: 805-830.

19. Iacono $C$, Serio G, Fugazzola $C$, Zamboni G, Bergamo Andreis IA, Zicari M, Dagradi A (1992) Cystic islet cell tumors of the pancreas. A clinicopathological report of two nonfunctioning cases and review of the literature. Int J Pancreatol 11: 199-208.

20. Davtyan H, Nieberg R, Rever HA (1990) Pancreatic cystic endocrine neoplasms. Pancreas 5: 230-233.

21. Strasser EJ, DeMarco SJ (1975) Postpartum hemorrhage into a large nonfunctioning islet cell tumor of the pancreas. Am Surg 41: 444-447.

22. Arnold R, Creutzfeldt C, Creutzfeldt W. Multiple hormone production of endocrine tumours of the gastrointestinal tract. In: James VHT (ed) Endocrinology, vol. 2. Amsterdam: Excerpta Medica Foundation 1977: 448-452.

23. Agarwal SK, Kester MB, Debelenko LV, Heppner C, Emmert-Buck MR, Skarulis MC, Doppman JL, Kim YS, Lubensky IA, Zhuang Z, Green JS, Guru SC, Manickam P, Olufemi SE, Liotta LA, Chandrasekharappa SC, Collins FS, Spiegel AM, Burns AL, Marx SJ (1997) Germline mutations of the MEN I gene in familial multiple endocrine neoplasia type I and related states. Hum Mol Genet 6: 1169-1175.

24. Teh BT, Kytölä S, Farnebo F, Bergman L, Wong FK, Weber G, Hayward N, Larsson C, Skogseid B, Beckers A, Phelan C, Edwards M, Epstein M, Alford F, Hurley D, Grimmond S, Silins G, Walters M, Stewart C, Cardinal J, Khodaei S, Parente F, Tranebjaerg L, Jorde R, Menon J, Khir A, Tan TT, 
Chan SP, Zaini A, Khalid BAK, Sandelin K, Thompson N, Brandi ML, Warth M, Stock J, Leisti J, Cameron D, Shepherd JJ, Öberg K, Nordenskjöld M, Salmela P (1998) Mutation analysis of the MEN I gene in multiple endocrine neoplasia type I, familial acromegaly, and familial isolated hyperparathyroidism. $J$ Clin Endocrinol Metab 83: 2621-2626.

25. Knudson AG (1971) Mutation and cancer, statistical study of retinoblastoma. Proc Natl Acad Sci USA 68: $820-823$. 